\title{
QUALITATIVE CHARACTERISTICS OF SMALL AND MEDIUM-SIZED ENTERPRISES AND REGIONAL DEVELOPMENT
}

\author{
[Kvalitatívne charakteristiky malého a stredného podnikania a regionálny \\ rozvoj]
}

\author{
Soňa Čapková ${ }^{1}$, Adriana Kluchová ${ }^{2}$ \\ ${ }^{1}$ Univerzita Mateja Bela, Ekonomická fakulta, Tajovského 10, 97590 Banská Bystrica \\ Email:sona.capkova@umb.sk \\ ${ }^{2}$ Univerzita Mateja Bela, Ekonomická fakulta, Tajovského 10, 97590 Banská Bystrica \\ Email:akluchova2@studenti.umb.sk
}

\begin{abstract}
Endogenous concepts of regional development are currently being enforced in the regional policy of the state. This fact is reflected in the specific attention given to small and medium-sized. Therefore, we have assumed differences in the qualitative characteristics of small and medium-sized enterprises in underdeveloped and developed regions, as well as the presence of a relationship between the level of a region's development and the qualitative characteristics of small and mediumsized enterprises. To identify the qualitative characteristics of small and medium-sized enterprises in underdeveloped and developed regions, we applied a two-step cluster analysis. An analysis of the results showed a smaller percentage representation of innovative elements in the qualitative characteristics of small and medium-sized enterprises in underdeveloped regions. By binary regression analysis, we have determined significance of qualitative characteristics of small and medium-sized enterprises in the underdeveloped and developed regions.
\end{abstract}

Keywords: binary logistic regression analysis, regional development, regional policy, small and medium-sized enterprises, two-step cluster analysis.

JEL classification: D22, O18, R12

Doručeno redakci: 29.5.2018; Recenzováno: 6.6.2018; 23.6.2018; Schváleno k publikování: 19.9.2018

\section{Úvod}

Regionálny rozvoj a MSP sú predmetom záujmu ekonómov v mnohých štátoch nielen v Slovenskej republike. V Slovenskej republike v roku 2017 MSP predstavovali 99,9 \% z celkového počtu aktívnych podnikatel'ských subjektov. Aj táto skutočnost' je dôvodom, prečo je potrebné sa činnosti MSP venovat' a prečo sa im venuje špecifická pozornost' zo strany ústredných orgánov verejnej správy aj v súvislosti s nerovnomerným rozvojom regiónov. Rozdielne ekonomické činnosti v regiónoch ovplyvňujú nerovnosti medzi regiónmi $\mathrm{v}$ úrovni ich rozvoja a teda aj v životnej úrovni obyvatel'stva.

Ciel'om state je posúdit' kvalitatívne charakteristiky MSP na úrovni územných štatistických jednotiek NUTS 3 a preukázat' vzt'ah medzi úrovňou rozvoja regiónov a kvalitatívnymi charakteristikami MSP. K posudzovaniu kvalitatívnych charakteristík MSP sme vzali do úvahy MSP $\mathrm{v}$ jednom zaostalom a jednom rozvinutom regióne. V prvej časti state sa zaoberáme teoretickými východiskami a metodikou skúmania. V d’alších častiach prezentujeme výsledky skúmania. V závere zhodnocujeme výsledky vzhl'adom k stanovenému ciel'u.

\section{Teoretické východiská}

Za dôležitý faktor endogénneho regionálneho rozvoja sa považujú MSP. Zvýšenú pozornost' im viacerí autori začali venovat' v období krízy označovanej v odbornej literatúre aj ako kríza „fordizmu“ (Hadjimichalis 2011), ked’ zohrali dôležitú rolu pri jej prekonávaní. Význam MSP 
pre regionálny rozvoj vyplýva z vlastností, ktoré sú im pripisované. Na niektoré z nich upozorňuje Strážovská (2012, s. 148) : 1. MSP sú v súčasnosti považované za najdôležitejší prvok národných ekonomík, 2. majú nezastupitel'nú úlohu v dynamickom rozvoji krajín s vyspelým trhovým hospodárstvom, 3 . sú vysoko prispôsobivé požiadavkám trhu a osobitne dopytu, 4. majú inovatívnu funkciu, 5. uspokojujú aj tie najnáročnejšie požiadavky zákazníkov a spotrebitel’ov, 6. vytvárajú nové pracovné miesta, a tým významne ovplyvňujú stav zamestnanosti. V činnosti MSP sa prejavujú nielen ich silné ale aj slabé stránky. Vo výskume uskutočnenom v roku 2006 Observatory of European SMEs (2007), oslovení predstavitelia MSP ako obmedzenia $\mathrm{v}$ podnikatel'skej činnosti uviedli problémy s kúpnou silou zákazníkov (46\%), problémy s administratívnymi predpismi (36\%), nedostatok kvalifikovanej pracovnej sily (35\%), príliš drahú pracovnú silu $(33 \%)$, problémy $\mathrm{s}$ infraštruktúrou (23\%), obmedzený prístup k financiám (21\%), zavádzanie novej technológie (17\%) a zavádzanie nových foriem organizácie (16\%).

Predpokladom k prekonávaniu obmedzení v podnikaní sa považujú inovácie. Významným faktorom pre tvorbu inovácii MSP predstavuje inovačne orientovaný manažment v podniku. V súčasnosti najdôležitejším typom manažmentu ekonomickej praxe a teórie na celosvetovej úrovni sa stáva znalostný manažment $\mathrm{v}$ podnikoch (Novotný 2011). Znalostným manažmentom respektíve riadením znalostí v MSP sa zaoberajú viaceré zahraničné štúdie. Desouza a Awazu (2006) identifikovali pät' špecifík v riadení vedomostí v MSP. Zamerali sa na inovatívne MSP. Prvým špecifikom sú poznatky, ktoré sú súčast’ou štruktúry organizácie, ked' dochádza k socializácii od manažéra až po zamestnancov. Druhým sú spoločné vedomosti (vedomosti známe všetkým členom organizácie). Pri definovaní troch špecifík prišli k záveru, že MSP majú dobrú schopnost' využivat' externé zdroje vedomostí, dôraz kladú na dobré spojenie s lokalitou a vedome alebo nevedome riadia vedomosti humanistickým smerom. Edvardson (2006) v rámci výskumu MSP na Islande prišiel k záveru, že MSP, v ktorých zaviedli program riadenia vedomostí prejavilo sa zvýšenie zručností zamestnancov, zlepšila sa komunikácia so zákazníkmi a zlepšilo sa rozhodovanie v podniku. Pozornost' je potrebné venovat' manažérom MSP. Kokavcová (2011) k prvkom znalostnej organizácie radí organizačné správanie a komunity, učenie sa a tvorba znalostí, výmena a odovzdávanie znalostí, organizačná kultúra, manažérske systémy na riadenie znalostí a informačno-komunikačné technológie.

Rozvoj regiónov sa stále viac zameriava na aktiváciu ekonomických a inovačných potenciálov smerujúcu k ,poznatkovo založenej spoločnosti“. Arnold, Mattes, Sandner (2014) porovnávali regionálne inovačné systémy viacerých regiónov Nemecka. Výsledkom štúdie je poznanie, že $\mathrm{v}$ úspešnom regionálnom inovačnom systéme sú dôležité kanály prenosu poznatkov v podobe osôb predstavujúcich l'udský kapitál, spin-off z univerzít a výskumných inštitúcií, $\mathrm{v}$ nákupe služieb výskumu a vývoja od tretích strán a spoluprácou a siet’ami. Spolupráca a prenos poznatkov predstavujú základ inovačného úspechu. Takéto poznatky sa stali východiskom pre regionálne politiky mnohých štátov. Podobne aj Regionálna inovačná politika SR na roky 2014 - 2020 podporuje spoluprácu MSP s regionálnymi a mimo regionálnymi partnermi a členstvo MSP v klastroch.

\section{Metodika}

Ako sme už uviedli, ciel'om state je posúdit' kvalitatívne charakteristiky MSP a preukázat' vzt'ah medzi úrovňou rozvoja regiónov a kvalitatívnymi charakteristikami MSP na úrovni územných štatistických jednotiek NUTS 3. Pre meranie rozdielnej úrovne rozvoja regiónov je $\mathrm{k}$ dispozícii viac metód. Použitie jednotlivých metód závisí od druhu výskumu, dostupnosti dát a od obsahu skúmanej problematiky. V analýzach, ktoré skúmajú úroveň rozvoja regiónu, 
najjednoduchšími kvantitatívnymi metódami sú nepriame metódy založené na škálovacích technikách a bodových metódach (Michálek 2012). Pri výbere reprezentanta zaostalého a rozvinutého regiónu na úrovni územných štatistických jednotiek. NUTS 3 v našom prieskume, aplikovali sme kritéria, ktoré sa vd'aka ich dostupnosti často používajú při národných alebo medzinárodných analýzach (napr. EÚ, OECD). K týmto kritériám patrí HDP na obyvatel'a, miera evidovanej nezamestnanosti, čisté peňažné príjmy domácností, miera rizika chudoby a použili sme metódu poradia. Každému kritériu sme priradili body podl'a hodnoty kritéria daného regiónu a so zohl'adnením toho či ide o kritérium s potrebnou čo najvyššou hodnotou alebo s čo najnižšou hodnotou. Dáta týchto ukazovatel'ov sme získali z regionálnych štatistík Štatistického úradu SR. Pri stanovení rozvinutého regiónu sme nevzali do úvahy výsledok Bratislavského kraja $z$ dôvodu, že dáta ukazovatel'ov tohto kraja sú ovplyvnené existenciou hlavného mesta SR Bratislavy v tomto kraji, ktorá je centrálnym mestom regiónu na úrovni štatistických územných jednotiek nielen NUTS 3 ale aj NUTS 1.

Pri analýze kvalitatívnych charakteristík MSP sme použili údaje získané dotazníkovým prieskumom a dvojkrokovú zhlukovú analýzu. Otázky v dotazníku sme formulovali vo všeobecnej oblasti (kraj, odvetvie, počet zamestnancov a rokov podnikania, realizácia podnikatel'skej činnosti $\mathrm{v}$ inom kraji ako je sídlo podniku a v zahraničí) a z oblasti v predchádzajúcej časti uvádzaných prvkov znalostnej organizácie (metódy komunikácie so zákazníkmi, zdroje používané k získavaniu nových znalostí, PC programy používané v podnikatel'skej činnosti, komunikačné kanály, používanie e-schopu k predaju a nákupom, podpora vzdelávania manažérov a zamestnancov, uskutočnenie zmien v podnikatel'skej činnosti za posledné tri roky, oblast' a percentuálne vyjadrenie hodnoty investovania do zmien, spôsoby spolupráce $\mathrm{s}$ inými subjektami). Pri doručovaní dotazníkov boli využité služby Slovenskej pošty. Dotazníky boli formulované v slovenskom a mad’arskom jazyku.

Základný súbor MSP v dotazníkovom prieskume tvorili domáce súkromné MSP právnické osoby s počtom zamestnancov od 5 do 249 vrátane. Výberový súbor MSP bol vytvorený jednoduchým náhodným výberom s opakovaním a zo základného súboru predstavoval $8 \%$. Zastúpenie jednotlivých kategórií MSP percentuálne zodpovedá percentuálnemu zastúpeniu v základnom súbore. K zist'ovaniu reprezentatívnosti výberového súboru použili sme chi-kvadrát test dobrej zhody.

Zhluková analýza je bežne aplikovanou metódou pre klasifikáciu viacrozmerných objektov do tried čiže zhlukov (Meloun 2012) v rôzne zameraných výskumoch. Medzi viacrozmerné objekty radíme aj MSP. Pri vol'be metódy zhlukovej analýzy, museli sme vziat' do úvahy vel'kost' súboru. Dvojkrokovou zhlukovou analýzou dochádza k rozdeleniu MSP z obidvoch regiónov do zhlukov s určitými kvalitatívnymi charakteristikami na základe ich nepodobnosti.

Aplikovaním binárnej logistickej regresnej analýzy sme identifikovali významné kvalitatívne charakteristiky MSP pre vybrané regióny. Pri výbere druhu regresnej analýzy je potrebné zohl'adňovat' typ dát, ktoré máme k dispozícii. Meloun, Militký, Hill (2012) upozorňujú na rozdiel medzi logistickou a lineárnou regresiou. Kým v lineárnej regresií vysvetl'ovanou, závislou premennou môže byt' len spojitá veličina (intervalová), v logistickej regresnej analýze môžu byt' použité ostatné premenné. Logistická regresná analýza predikuje pravdepodobnost' nastatia javu. Vysvetl'ovanú, závislú premennú predstavujú regióny, ktorej kategoriálna veličina nadobúda dve úrovne 1 a 0 (Prešovský kraj a Trnavský kraj), preto k stanoveniu významných kvalitatívnych charakteristík MSP pre vybrané regióny, aplikovali sme binárnu logistickú regresnú analýzu. $\mathrm{K}$ testovaniu významných regresných koeficientov sme použili Waldovo testovacie kritérium (Wald). Zároveň bola použitá metóda postupného 
vylučovania premenných (Backward Stepwise). Pri metóde Backward Stepwise sú všetky vysvetl'ujúce premenné (charakteristiky) naraz vložené do systému a v jednotlivých krokoch logistickou regresnou analýzou sa postupne vylučujú menej významné charakteristiky. V poslednom 32. kroku ostalo 23 najvýznamnejších charakteristík MSP, ktoré sú odlišné podl'a toho v ktorom regióne sa nachádzajú. Hodnota $\operatorname{Exp}(b)$ vyjadruje za platnosti modelu kol'ko krát sa zmení šanca nastatia javu (úroveň 1) oproti jeho nenastatiu, ak sa zmení príslušná vysvetl'ujúca premenná o jednu jednotku, pri nezmenených hodnotách ostatných vysvetl'ujúcich premenných. Pokial' hodnota $\operatorname{Exp}(b)$ je vyššia ako 1, pri zmene hodnoty jednej premennej o jednu jednotku, šanca zmeny $\mathrm{k} 1$. úrovni je o viac ako $1 \mathrm{x}$ vyššia. Úroveň 1 predstavuje Prešovský kraj. Zdrojom dát vysvetl'ujúcich premenných predstavovali dáta $\mathrm{z}$ výberového súboru MSP získané dotazníkovým prieskumom. Pri aplikácii logistickej regresnej analýzy, použili sme štatistický programu SPSS.

\section{Kvalitatívne charakteristiky MSP vybraných regiónov}

K výberu reprezentanta zaostalého a rozvinutého regiónu v SR sme použili štatistickú metódu poradia. Na základe výsledkov uskutočneného merania úrovne rozvoja regiónov, zvolili sme Prešovský kraj ako reprezentanta zaostalých a Trnavský kraj rozvinutých regiónov.

\subsection{Reprezentatívnost' súboru}

Základný súbor tvorilo 4673 domácich súkromných MSP z Trnavského a Prešovského kraja s počtom zamestnancov od 5 do 249 vrátane. Z tohto počtu stredné podniky predstavovali $318(6,81 \%)$, malé podniky $1992(42,63 \%)$ a mikropodniky s počtom zamestnancov 5 až 9 zamestnancov $2363(50,57 \%)$.

Výberový súbor tvorilo 374 malých a stredných podnikov - právnických osôb, čo je $8 \%$ podnikov základného súboru. Z 374 MSP výberového súboru 26 podnikov predstavovali stredné podniky (6,95\%), 160 malé podniky (42,78\%) a 188 mikropodniky $(50,26 \%)$. Zastúpenie MSP v ich jednotlivých kategóriách je v rovnakom počte zastúpené z Trnavského a Prešovského kraja.

Tabul'ka 1: Návratnost' dotazníkov

\begin{tabular}{|l|l|l|l|l|}
\hline \multicolumn{1}{|c|}{ Počet dotazníkov/MSP } & Mikropodniky & Malé podniky & Stredné podniky & MSP celkom \\
\hline Počet rozposlaných dotazníkov & 683 & 575 & 92 & 1350 \\
\hline Počet vrátených vyplnených dotazníkov & 190 & 160 & 26 & 376 \\
\hline Počet neúplne vypísaných dotazníkov & 2 & 0 & 0 & 2 \\
\hline Počet dotazníkov použitých vo výskume & 188 & 160 & 26 & 374 \\
$27,7 \% \mathrm{z} 1350$ \\
\hline
\end{tabular}

Zdroj: Vlastné spracovanie.

Overenie reprezentatívnosti súboru ako aj aplikáciu dvojkrokovej zhlukovej analýzy sme uskutočnili v programe SPSS. Ku kontrole reprezentatívnosti výberového súboru sme použili chi-kvadrát test dobrej zhody. Štatistický test bol vyhodnotený na hladine významnosti 0,05 .

Tabul'ka 2: Overovanie reprezentatívnosti súboru

\begin{tabular}{|l|r|r|r|}
\hline Chi-Square Test, Frequencies O4_kod & & & \\
\hline & $\begin{array}{c}\text { Observed } \\
\mathrm{N}\end{array}$ & $\begin{array}{c}\text { Expected } \\
\mathrm{N}\end{array}$ & Residual \\
\hline Mikropodniky 5 - 9 zamestnancov & 188 & 189,1 & $-1,1$ \\
\hline Malé podniky 10 - 49 zamestnancov & 160 & 159,4 &, 6 \\
\hline Stredné podniky 50 - 249 zamestnancov & 26 & 25,4 &, 6 \\
\hline Total & 374 & & \\
\hline
\end{tabular}

Zdroj: Výstup z SPSS programu.

Chi-kvadrát test dobrej zhody preukázal reprezentatívnost' výberového súboru $(\mathrm{p}=0,989)$. 


\subsection{Posudzovanie kvalitatívnych charakteristík MSP}

V dvojkrokovej zhlukovej analýze na základe najvýznamnejších 8 premenných sa prejavila vel'mi dobrá zhlukovacia schopnost' rozdelit' objekty súboru do dvoch zhlukov. Túto skutočnost' zobrazuje obrázok 1.

Obrázok 1: Kvalita zhlukovania v súbore MSP

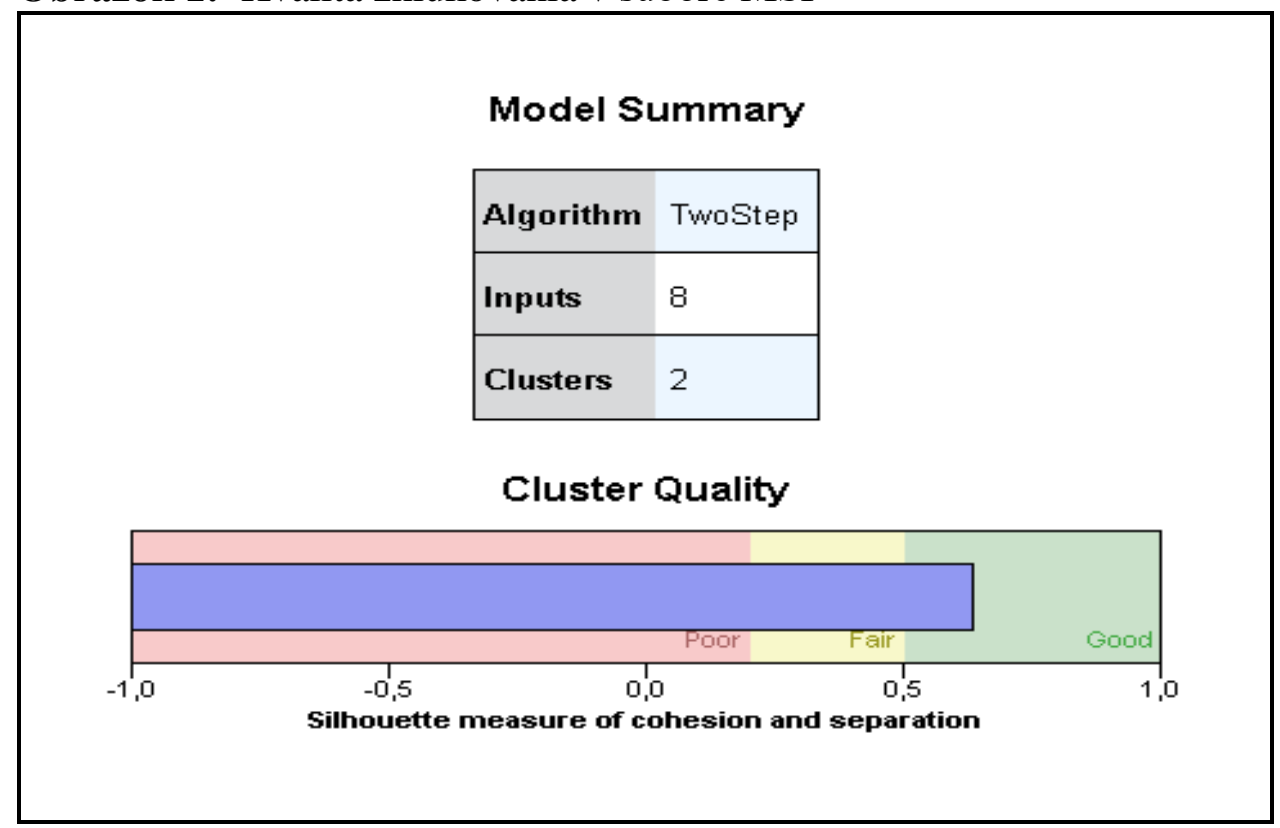

Zdroj: Výstup z SPSS programu.

Metóda dvojkrokovej zhlukovej analýzy umožnila identifikovat' osem najdôležitejších premenných pre klasifikáciu MSP do zhlukov:

1. Neuskutočnenie zmeny v žiadnej oblasti podnikatel'skej činnosti v priebehu 3 rokov

2. Kol'ko krát ste uskutočnili zmeny v priebehu 3 rokov v podnikatel'skej činnosti?

3. Aké percento $\mathrm{z}$ celkového obratu $\mathrm{v}$ priebehu 3 rokov ste použili na uskutočňované zmeny v podnikatel'skej činnosti?

4. Uskutočnenie zmien $\mathrm{v}$ podnikatel'skej činnosti $\mathrm{v}$ oblasti procesu (technológia a metódy postupov, logistika, distribúcia produkcie )

5. Uskutočnenie zmien $v$ organizácii a riadení podniku

6. Uskutočnenie zmien $v$ oblasti marketingovej činnosti

7. Uskutočnenie zmien $\mathrm{v}$ oblasti produkcie

8. Používanie manažérskeho PC software v podnikatel'skej činnosti

Analýzou kritérii zist’ujeme, že všetky kritériá sú s inovatívnymi prvkami. Potvrdzuje sa tým teoretický poznatok o význame prvkov inovácií v podnikatel'skej činnosti MSP. Kritéria zhlukovania (charakteristiky) sú v dvojkrokovej zhlukovej analýze uložené v tzv. CF-strome a samotný algoritmus je realizovaný v dvoch fázach. V prvej fáze boli MSP na základe nepodobnosti zhlukované do podzhlukov a $\mathrm{v}$ druhej fáze boli tieto podzhluky tiež na základe nepodobnosti zhlukované do konečných dvoch zhlukov. Počet MSP z jednotlivých krajov v dvoch zhlukoch zobrazuje tabul'ka 3. Pri posudzovaní kvalitatívnych charakteristík MSP, vychádzali sme z kvalitatívnych charakteristík MSP v týchto zhlukoch. 
Tabul'ka 3: Početné rozdelenie MSP do 2 zhlukov dvojkrokovou zhlukovou analýzou

\begin{tabular}{|c|c|c|c|c|c|}
\hline TSC_1599 & & Frequency & Percent & Valid Percent & Cumulative Percent \\
\hline $\begin{array}{ll}1 & \text { Valid }\end{array}$ & $\begin{array}{c}1 \\
2 \\
\text { Total } \\
\end{array}$ & $\begin{array}{l}103 \\
112 \\
215 \\
\end{array}$ & $\begin{array}{l}47,9 \\
52,1 \\
100 \\
\end{array}$ & $\begin{array}{c}47,9 \\
52,1 \\
100\end{array}$ & $\begin{array}{c}47,9 \\
100\end{array}$ \\
\hline $2 \quad$ Valid & $\begin{array}{c}1 \\
2 \\
\text { Total }\end{array}$ & $\begin{array}{c}84 \\
75 \\
159\end{array}$ & $\begin{array}{l}52,8 \\
47,2 \\
100\end{array}$ & $\begin{array}{c}52,8 \\
47,2 \\
100\end{array}$ & $\begin{array}{c}52,8 \\
100\end{array}$ \\
\hline
\end{tabular}

Zdroj: Výstup z SPSS programu.

Zhluk 1 tvorí o 56 (o 14,97\% z 374) viac MSP ako zhluk 2. Z hl'adiska regiónov, v zhluku 1 väčšie početné zastúpenie MSP sa prejavilo z Prešovského kraja (o 4,19\% z 215). Zhluk 2 tvorí o 5,66\% viac podnikov z Trnavského kraja. Analýzou dát získaných dvojkrokovou zhlukovou analýzou identifikovali sme rozdiely $\mathrm{v}$ kvalitatívnych charakteristikách MSP $\mathrm{v}$ jednotlivých zhlukoch. Rozdiely v kvalitatívnych charakteristikách MSP medzi zhlukom 1 a zhlukom 2 zobrazuje tabul'ka 4.

Tabul'ka 4: Percentuálne rozdiely v kvalitatívnych charakteristikách MSP v zhluku 1 v porovnaní so zhlukom 2

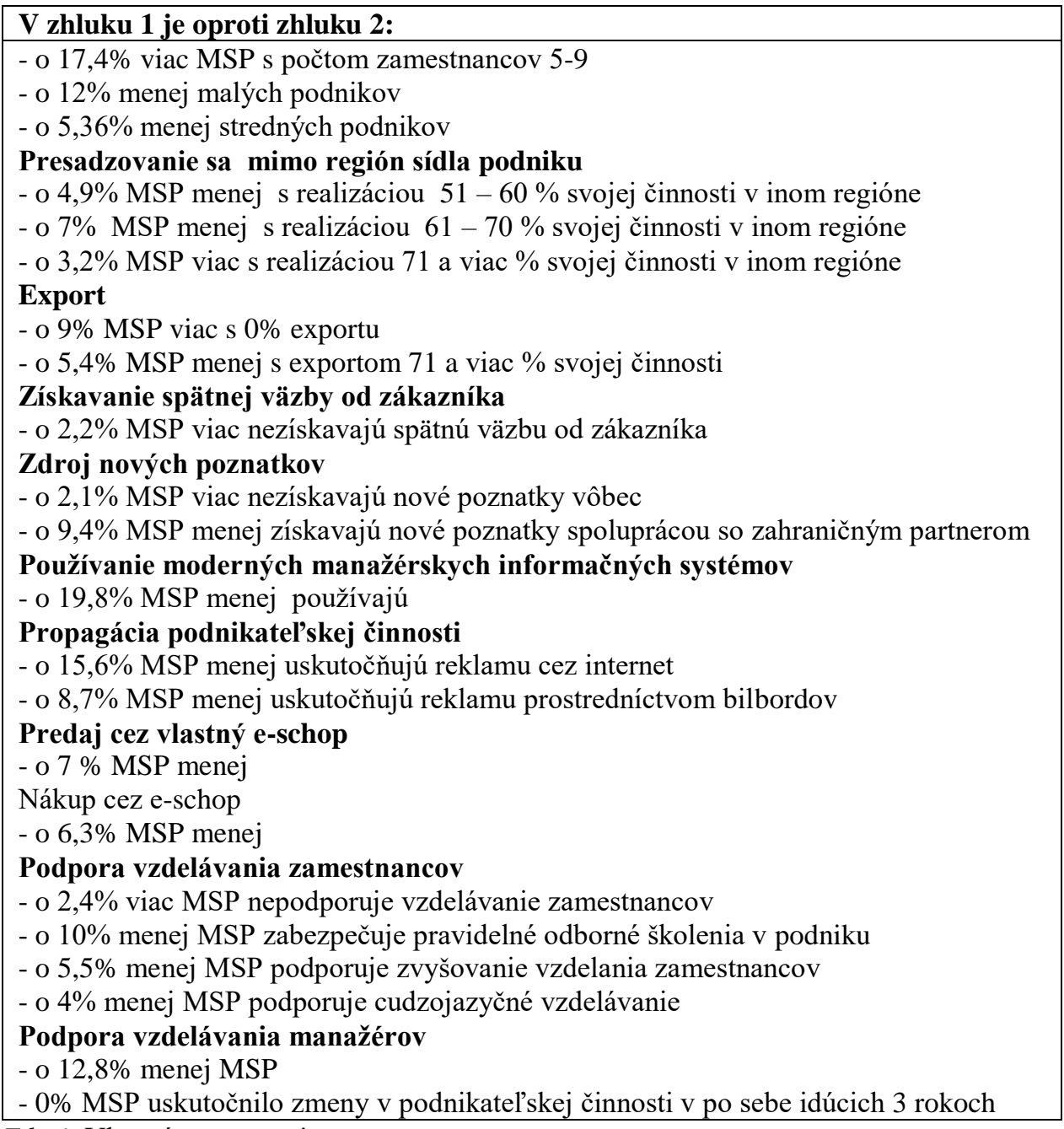

Zdroj: Vlastné spracovanie

Z výsledkov dvojkrokovej zhlukovej analýzy vyplýva menšie percentuálne zastúpenie niektorých inovatívnych prvkov v kvalitatívnych charakteristikách MSP v zhluku 1. Podpora vzdelávania manažérov, zamestnancov a používanie moderných manažérskych informačných 
systémov sú predpokladom pre tvorbu inovácií v MSP. Táto skutočnost' ovplyvňuje uskutočňovanie inovácii MSP $\mathrm{v}$ regiónoch. V zhluku 1 sme pozorovali väčší počet MSP (z čoho vyplýva menší počet inovatívnych MSP v regiónoch) a väčšie zastúpenie MSP z Prešovského kraja.

Z hl'adiska odvetvia, dvojkroková zhluková analýza nepreukázala dôležitost' odvetvia pre kvalitatívne charakteristiky MSP v zhluku 1 a v zhluku 2. Ani v jednom zhluku sa neprejavilo výrazne vyššie percentuálne zastúpenie MSP v niektorom odvetví. Pri porovnaní zhlukov navzájom najväčší percentuálny rozdiel sa prejavil v odvetví stavebníctva, v ktorom väčšie percentuálne zastúpenie MSP sa prejavil v podnikoch predstavujúci zhluk 1 (o 8,5\%). Inovácie či export môžu MSP uskutočňovat' v každom odvetví. Iná otázka je tvorba pridanej hodnoty v odvetviach, mzdy, odbornost' činností v odvetviach, to sú však ukazovatele odvetvia a neovplyvňujú priamo kvalitatívne charakteristiky MSP a prítomnost' inovatívnych prvkov v charakteristikách MSP. Odvetvie v regióne samozrejme je potrebné sledovat' $\mathrm{z}$ hladiska potrieb podnikov a odvetvového zastúpenia ekonomicky aktívneho obyvatel'stva $\mathrm{v}$ regióne a z hl'adiska investorov. Výsledky dvojkrokovej zhlukovej analýzy smerujú skôr k odporúčaniam ekonómov Martina a Sunleya (2007), ktorí vo svojej štúdii upozorňujú na význam trhov pre znalosti a na potrebu venovat' vel'kú pozornost' regionálnym a lokálnym trhom.

\section{Významné kvalitatívne charakteristiky MSP v Prešovskom a Trnavskom kraji}

Vzhl'adom na charakter dát závislej premennej (kategoriálne dáta) a nadobúdania jej 2 úrovní, aplikovali sme pri stanoveniu významných kvalitatívnych charakteristík MSP v Trnavskom a Prešovskom kraji binárnu logistickú regresnú analýzu.

Tabul'ka 5: Prekódovanie hodnôt k úrovniam rozvoja regiónu

\begin{tabular}{|l|lr|}
\hline \multicolumn{2}{|c|}{ Dependent Variable Encoding } \\
\hline Original Value & Internal Value & 0 \\
\hline 1 Trnavský kraj & & 1 \\
\hline 2 Prešovský kraj & & \\
\hline
\end{tabular}

Zdroj: Výstup z SPSS programu.

V d'alšej analýze sme použili tabul'ku 6, v ktorej sme čísla otázok významných regresných premenných nahradili konkrétnou kvalitatívnou charakteristikou MSP. 
Tabul'ka 6: Významné charakteristiky MSP v Prešovskom a Trnavskom kraji

\begin{tabular}{|c|c|c|c|c|}
\hline с̌.o. & Charakteristika & $\mathbf{b}$ & p-hodnota & $\operatorname{EXP}(\mathbf{b})$ \\
\hline $\mathrm{O} 2$ & & & 0,008 & \\
\hline $\mathrm{O} 2(1)$ & Odvetvie - priemysel & 0,172 & 0,828 & 1,188 \\
\hline $\mathrm{O} 2(2)$ & Odvetvie - stavebníctvo & 0,759 & 0,356 & 2,136 \\
\hline $\mathrm{O} 2(3)$ & Odvetvie - obchod, pohostinstvo a ubytovanie & $-0,697$ & 0,399 & 0,498 \\
\hline $\mathrm{O} 2(4)$ & Odvetvie - doprava a skladovanie & $-1,253$ & 0,194 & 0,286 \\
\hline $\mathrm{O} 2(5)$ & Odvetvie- Informácie a komunikácie & 2,120 & 0,139 & 8,329 \\
\hline $\mathrm{O} 2(6)$ & Odvetvie - vybrané trhové služby &, 076 & 0,924 & 1,079 \\
\hline O6 & Podnikanie v inom kraji ako je sídlo & $-0,114$ & $\mathbf{0 , 0 1 3}$ & 0,892 \\
\hline $\mathrm{O} 7$ & Zahraničný obchod & 0,252 & $\mathbf{0 , 0 0 0}$ & 1,287 \\
\hline O9a & $\begin{array}{l}\text { Zdroje nových poznatkov a informácií } \\
\text { - rodina }\end{array}$ & 1,785 & 0,003 & 5,962 \\
\hline O9c & $\begin{array}{l}\text { Zdroje nových poznatkov a informácií } \\
\text { - odborné časopisy }\end{array}$ & $-0,765$ & 0,009 & 0,465 \\
\hline O9e & $\begin{array}{l}\text { Zdroje nových poznatkov a informácií } \\
\text { - Internet }\end{array}$ & $-1,094$ & $\mathbf{0 , 0 0 0}$ & 0,335 \\
\hline O9f & $\begin{array}{l}\text { Zdroje nových poznatkov a informácí } \\
\text { - školenia a kurzy }\end{array}$ & 1,349 & $\mathbf{0 , 0 0 0}$ & 3,855 \\
\hline $\mathrm{O} 10 \mathrm{c}$ & $\begin{array}{l}\text { Počítačové programy } \mathrm{v} \text { oblasti } \\
\text { - personalistiky }\end{array}$ & $-1,384$ & $\mathbf{0 , 0 0 0}$ & 0,250 \\
\hline O10d & $\begin{array}{l}\text { Počítačové programy v oblasti } \\
\text { - vedenia účtovníctva }\end{array}$ & 0,593 & 0,063 & 1,810 \\
\hline O10e & $\begin{array}{l}\text { Počítačové programy v oblasti } \\
\text { - pokladničného systému }\end{array}$ & 0,976 & $\mathbf{0 , 0 0 3}$ & 2,653 \\
\hline O11f & $\begin{array}{l}\text { Spôsob propagácie } \\
\text { - účast' na charitatívnych podujatiach }\end{array}$ & 1,617 & $\mathbf{0 , 0 0 1}$ & 5,039 \\
\hline O14a & $\begin{array}{l}\text { Podpora vzdelávania zamestnancov } \\
\text { - pravidelné odborné školenia v podniku }\end{array}$ & $-0,542$ & $\mathbf{0 , 0 3 6}$ & 0,582 \\
\hline $\mathrm{O} 14 \mathrm{~d}$ & $\begin{array}{l}\text { Podpora vzdelávania zamestnancov } \\
\text { - v oblasti zdokonal'ovania sa v cudzích jazykoch }\end{array}$ & $-1,844$ & 0,004 & 0,158 \\
\hline $\mathrm{O} 18 \mathrm{c}$ & Zmeny v podniku v oblasti procesu podnikania & $-0,725$ & $\mathbf{0 , 0 7 5}$ & 0,485 \\
\hline O18d & Zmeny v podniku v oblasti marketingu & $-1,123$ & $\mathbf{0 , 0 0 7}$ & 0,325 \\
\hline $\mathrm{O} 18 \mathrm{e}$ & Neuskutočnil zmeny & $-0,714$ & 0,046 & 0,489 \\
\hline $\mathrm{O} 20 \mathrm{a}$ & Spolupráca MSP v klastri & 1,338 & 0,019 & 3,811 \\
\hline O20f & Úzka naviazanost' na vel'kú firmu & 0,765 & $\mathbf{0 , 0 1 9}$ & 2,149 \\
\hline Constant & & 0,853 & 0,347 & 2,348 \\
\hline
\end{tabular}

Zdroj: Vlastné spracovanie podla výstupu z SPSS programu.

Kvalitatívne charakteristiky MSP, ktorých p-hodnota $<0,1$ a hodnotu $\operatorname{EXP(b)~majú~vyššiu~}$ ako 1 predstavujú charakteristiky, ktorých zvýšenie šance zmeny je typické skôr pre podniky v Prešovskom kraji. Tieto hodnoty sme pozorovali v prípade kvalitatívnych charakteristík: Zahraničný obchod, Zdroje nových poznatkov a informácií - rodina, Zdroje nových poznatkov a informácií - školenia a kurzy, Počítačové programy v oblasti - vedenia účtovníctva, Počítačové programy v oblasti - pokladničného systému, Spôsob propagácie účast' na charitatívnych podujatiach, Spolupráca MSP v klastri, Úzka naviazanost' na vel'kú firmu.

Nižšia hodnota ako $\mathrm{p}=0,1$ a zároveň ale nižšia hodnota $\mathrm{EX}(\mathrm{b})$ ako 1 , prejavila sa v kvalitatívnych charakteristikách MSP: Podnikanie v inom kraji ako je sídlo, Zdroje nových poznatkov a informácií - odborné časopisy, Zdroje nových poznatkov a informácií - internet, Počítačové programy $\mathrm{v}$ oblasti - personalistiky, Podpora vzdelávania zamestnancov pravidelné odborné školenia v podniku, Podpora vzdelávania zamestnancov - v oblasti zdokonal'ovania sa v cudzích jazykoch, Zmeny v podniku v oblasti marketingu, Neuskutočnil zmeny, Zmeny v oblasti procesu podnikania. V týchto kvalitatívnych charakteristikách je zvýšenie šance zmeny typické skôr pre podniky v Trnavskom kraji. 
Porovnaním kvalitatívnych charakteristík zist’ujeme, že medzi významnými charakteristikami pre podniky v Prešovskom kraji chýba akákol’vek forma podpory vzdelávania zamestnancov a uskutočňovanie zmien v podnikatel'skej činnosti MSP.

\section{Vzt’ah medzi úrovňou rozvoja regiónov a kvalitatívnymi charakteristikami MSP}

Ako sme v úvode naznačili, predpokladali sme nielen rozdielne kvalitatívne charakteristiky MSP v zaostalých a rozvinutých regiónoch, ale aj existenciu vzt'ahu medzi úrovňou rozvoja regiónov a kvalitatívnymi charakteristikami MSP. Preskúmanie existencie vzt'ahu sme uskutočnili opätovnú analýzu uskutočnenej dvojkrokovej zhlukovej analýzy. Podrobnou analýzou postupu a výsledkov zist'ujeme, že MSP boli do dvoch zhlukov rozdelené podl'a 8 charakteristík MSP. Vo všetkých ide o charakteristiky súvisiace s inováciami, to znamená, že dvojkroková zhluková analýza preukázala, že existencia inovačných prvkov v kvalitatívnych charakteristikách MSP má vplyv na úroveň rozvoja regiónov, pretože práve $\mathrm{v}$ týchto charakteristikách sa najviac MSP odlišujú.

\section{Záver}

Analýza výsledkov dvojkrokovej zhlukovej analýzy preukázala rozdiely v kvalitatívnych charakteristikách MSP, ktoré sa prejavili v menšom percentuálnom zastúpení inovatívnych prvkov v kvalitatívnych charakteristikách MSP, ktoré tvoria zhluk $1 \mathrm{~s}$ prevahou podnikov zo zaostalého regiónu. Zároveň v tomto zhluku sa vyskytovalo o 14,97\% viac MSP ako v zhluku 2. Inovácie sú $\mathrm{v}$ súčasnosti považované za dôležitý faktor regionálneho rozvoja a konkurencieschopnosti MSP. Z výsledkov vyplýva, že $\mathrm{v}$ zhluku 1 sa vyskytuje menší percentuálny počet MSP, ktoré podporujú vzdelávanie manažérov a zamestnancov. V MSP zhluku 2 sa prejavila aj väčšia pestrost' foriem podpory vzdelávania zamestnancov. So vzdelávaním manažérov následne súvisí aj používanie moderných manažérskych systémov v riadení podniku, ktoré vo väčšej miere používajú MSP tvoriace zhluk 2. Dôležitú rolu nielen pre tvorbu inovácií, ale aj k presadzovaniu sa na zahraničných trhoch zohráva aj spolupráca so zahraničnými partnermi, ktorá sa vyskytuje vo väčšej miere u MSP v zhluku 2. Toto nižšie percentuálne zastúpenie inovatívnych prvkov v podnikatel'skej činnosti v MSP, ktoré tvoria zhluk 1 sa prejavilo aj $\mathrm{v}$ neuskutočňovaní zmien $\mathrm{v}$ MSP $\mathrm{v}$ priebehu po sebe idúcich troch rokoch.

Binárnou logistickou regresnou analýzou sme zistili, že medzi významnými charakteristikami podnikov v Prešovskom kraji chýba niektorá $\mathrm{z}$ foriem podpory vzdelávania zamestnancov a uskutočňovanie zmien $v$ podnikatel'skej činnosti, čo poukazuje na nižšie inovačné aktivity MSP v tomto kraji. Zároveň v obidvoch krajoch chýba podpora vzdelávania manažérov, čo ovplyvňuje inovačné aktivity MSP. Vzhl'adom na výsledky zahraničných štúdii (Salojärvi, Furu, Sveiby 2005; Edvardsson 2006; Desouza, Awazu 2006) a d'alších, mala by sa tejto oblasti, ako aj podpore inovačných aktivít MSP a budovaniu efektívnych regionálnych inovačných systémov venovat' zvýšená pozornost' na regionálnej úrovni nielen zo strany MSP ale aj zo strany verejnej správy.

\section{Literatúra}

[1] ARNOLD, M., A. MATTES and P. SANDNER, 2014. Regionale Innovationssysteme im Vergleich. In DIW-Wochenbericht [online]. 2014 [vid. 12. máj 2015], s. 79-87. Dostupné na internete: http://www.econstor.eu/bitstream/10419/91602/1/777543788.pdf

[2] DESOUZA, C. K. and Y. AWAZU, 2006. Knowledge management at SMEs:five peculiarities. In JOURNAL OF KNOWLEDGE MANAGEMENT [online]. 2006 [vid. 6. máj 2018], $\quad$ s. $\quad 32 \quad-\quad$ 43. $\quad 32$ Dostupné na internete: 
https://www.researchgate.net/profile/Kevin_Desouza/publication/220363579_Knowledg e_management_at_SMEs/links/55c5f7d108aebc967df52f32/Knowledge-management-atSMEs.pdf

[3] EDVARDSSON, I. R., 2006. Knowledge management in SMEs: the case of Icelandic firms. In Knowledge Management Research \& Practice [online]. 2006 [vid. 6. máj 2018], $\quad$ s. $275 \quad$ - 282. Dostupné na internete: https://www.researchgate.net/profile/Ingi_Edvardsson/publication/234027404_Knowledg e_management_in_SMEs_The_case_of_Icelandic_firms/links/0912f50ef0f1883be60000 00.pdf

[4] HADJIMICHALIS, C., 2011. SMEs, entrepreneurship and local/regional development. In Handbook of Local and Regional Development. [online]. Routledge, 2011[vid. 12. marec 2018], s. 381-393. Dostupné na internete: http://www.regscience.hu:88/record/418/files/DEMO-BOOK-2017-055.pdf?version=1

[5] KOKAVCOVÁ, D., 2011. Nová paradigma znalostného manažmentu. Banská Bystrica: lura Edition 2011. 92 s. ISBN 978-80-8078-395-2.

[6] MARTIN, R. and P. SUNLEY, 2007. Complexity thinking and evolutionary economic geography. In: Journal of Economic Geography [online]. 2007 [vid. 12. máj 2015], s. $573-601.6$ Dostupné na internete: https://scholar.google.sk/scholar?hl=sk\&as_sdt=0\%2C5\&q=Complexity+thinking+and+ evolutionary+economic+geography\&btnG=

[7] MELOUN, M., J. MILITKÝ a M. HILL, 2012. Statistická analýza vícerozměrných dat v príkladech. Praha: ACADEMIA, 2012. 760 s. ISBN 978-80-200-2071-0.

[8] MICHÁLEK, A., 2012, Vybrané metódy merania regionálnych disparít. In GEOGRAFICKÝ ČASOPIS/GEOGRAPHICAL JOURNAL [online]. Bratislava: Geografický ústav SAV, 2012 [vid. 10. máj 2015], s. 219 - 235. Dostupné na internete: http://www.sav.sk/journals/uploads/12121204Michalek.pdf

[9] NOVOTNÝ, J. a P. MIKULECKÝ, 2011. Znalostní management a jeho uplatnění v menších podnicích. In Scientific papers, Series D 2011/20 [online]. Pardubice: Univerzita Pardubice, [vid. 6. máj 2018], s. 102 - 113. Dostupné na internete: http://dspace.upce.cz/bitstream/handle/10195/42489/NovotnyJ_ZnalostniManagement_S P_FES_2011.pdf?sequence=1\&isAllowed=yhttp://www.rokovania.sk/Rokovanie.aspx/B odRokovaniaDetail?idMaterial $=23515$

[10] OBSERVATORY OF EUROPEAN SMES, 2007. Analytic report Observatory of European SMEs. 2007 [vid. 12. apríl 2018], 267 s. Dostupné na internete: http://ec.europa.eu/commfrontoffice/publicopinion/flash/fl196_en.pdf

[11] SALOJÄRVI, S., P. FURU and E. K. SVEIBY, 2005. Knowledge Management and Growth in Finnish SMEs. In Journal of Knowledge Management [online]. 2005 [vid. 6. máj 2018], $\quad$ s. 1 - 21. Dostupné na internete: https://www.researchgate.net/profile/Karl_Erik_Sveiby/publication/220363551_Knowled ge_Management_and_Growth_in_Finnish_SMEs/links/5436c51a0cf2dc341db4c139.pdf

[12] STRÁŽOVSKÁ, H., 2012. Malé a stredné podniky v ekonomike Slovenska. In: Výzvy a perspektívy cestovného ruchu v Slovenskej republike v Bratislave 28. 11. 2012. Bratislava: EU v Bratislave, Obchodná fakulta, 2012, s. 147 - 148. ISBN978-80-225-35-34-2. 